\title{
Continuous monitoring of the cytoplasmic pH in Methanobacterium thermoautotrophicum using the intracellular factor $F_{420}$ as indicator
}

\author{
Peter von Felten and Reinhard Bachofen
}

Institute of Plant Biology, University of Zürich, Zollikerstraße 107, $\mathrm{CH}-8008$ Zürich, Switzerland
Author for correspondence: Reinhard Bachofen. Tel: +41163482 80. Fax: +4116348204. e-mail: bachofen@botinst.unizh.ch

\begin{abstract}
The absorption spectrum of factor $\mathrm{F}_{420}$ changes depending on the $\mathrm{pH}$ and the redox state of the cytoplasm. Specific wavelengths were used to calibrate absorption changes to allow the measurement of changes in the cytoplasmic pH in Methanobacterium thermoautotrophicum. Upon a hydrogen pulse, a rapid efflux of protons was observed. Under these energized conditions, the $\Delta \mathrm{pH}$ amounts to 0.2-0.4 pH units at pH 6.6, and 0.6-0.8 pH units at pH 6.0. It decays within 10-20 s. In parallel, a sodium gradient is formed which has a slightly longer lifetime. Both $\Delta \mathrm{pH}$ and $\Delta \Psi$ contribute to the proton-motive force present during methanogenesis. The energy-conversion rate, as indicated by the decay of the energized state of the cell, is fastest under growth conditions, i.e. at pH 6.9 and at a temperature of $58^{\circ} \mathrm{C}$.
\end{abstract}

Keywords: cytoplasm, $\mathrm{pH}$ gradient, intracellular $\mathrm{pH}$, protonmotive force, methanogenic bacteria

\section{INTRODUCTION}

The $\mathrm{pH}$ of the cell cytoplasm is a critical parameter controlling a variety of cellular processes. In most organisms, the $\mathrm{pH}$ in the cytoplasm is maintained over a range of approximately two $\mathrm{pH}$ units around neutrality (Padan et al., 1981). However, this $\mathrm{pH}$ homeostasis is dependent on energy. The $\mathrm{pH}$ surrounding cells or cell aggregates is the main environmental factor that strongly determines growth and metabolism. It is crucial to the size of the $\mathrm{pH}$ gradient across the cell membrane, which forms an essential part of the proton-motive force driving biological energy conversion.

In suspension cultures of micro-organisms, the external $\mathrm{pH}$ is easily followed by using electrodes. In contrast, the determination of cytoplasmic $\mathrm{pH}$ in cells as small as bacteria is more difficult. Certain methods are based on the distribution of radiolabelled weak acids or bases whereby the cells (after incubation) are separated from the medium by rapid filtration or centrifugation. As sampling is periodic, the data from these methods are not continuous (Padan et al., 1981). Spectrometric methods, however, either absorption or fluorescence

Abbreviations: BESA, bromoethanesulfonic acid; CF, carboxyfluorescein; TCS, tetrachlorosalicylanilide. spectrometry, use specific $\mathrm{pH}$ indicators to monitor the cytoplasmic $\mathrm{pH}$ continuously.

The first descriptions of $\mathrm{pH}$ estimations using dyes (fluorogenic esters) were given by Thomas et al. (1979, 1982) for tumour cells and bacteria. The prerequisites of the method are as follows: (1) the cells must be permeable to these colourless and non-fluorescent esters; (2) the indicators must be concentrated in the cells; (3) an intracellular esterase must cleave off an absorbing or fluorescing species; (4) the membrane must be impermeable to the negatively charged species formed by the hydrolysis (so that the indicator remains in the cells, at least for the duration of the experiment); (5) a calibration curve must be obtained; and (6) no other cellular compounds should interfere (by absorbance or fluorescence) with the marker compound. Generally, not all of these prerequisites are fulfilled. To prevent leakage of the $\mathrm{pH}$-indicator, a dye forming covalent bonds with cytoplasmic compounds has been developed (Breeuwer et al., 1996). However, the question as to whether or not indicator dyes interact with cytoplasmic proteins and cause erroneous results remains open to debate (Yassine et al., 1997). To compensate for unequal uptake of the dye and varying esterase activity, fluorescence ratios from two wavelengths were analysed to follow the $\mathrm{pH}$ (Aono et al., 1997). Recently, fluorescence ratio microscopy imaging even made it possible to follow the $\mathrm{pH}$ of single bacterial cells in a mixed culture 
(Siegumfeldt et al., 1999). These studies demonstrate the versatility of spectroscopic techniques in the investigation of $\mathrm{pH}$ homeostasis and the dynamics of $\mathrm{pH}$ changes during energy transduction.

The metabolism (including energy transduction) of methanogenic bacteria has been studied intensively in recent decades, as reviewed, for example, by Deppenmeier et al. (1996) and Schäfer et al. (1999). In the process of the stepwise reduction of $\mathrm{CO}_{2}$ to $\mathrm{CH}_{4}$ by $\mathrm{H}_{2}$, protons are extruded, giving rise to a $\mathrm{pH}$ gradient, which, along with a $\mathrm{Na}^{+}$gradient and the membrane potential, is an important component of the driving force for ATP synthesis in a chemiosmotic mechanism. Changes in membrane potential upon the energization of whole cells of Methanobacterium thermoautotrophicum have been measured by Butsch \& Bachofen (1984). Using the dye carboxyfluorescein (CF), Bachofen $\&$ Butsch (1986) demonstrated, qualitatively, the formation of a $\mathrm{pH}$ gradient upon cell energization. The length of the signal correlated with the partial pressure of hydrogen gas introduced, whereas its magnitude was independent of the partial pressure over the range $20-80 \%(\mathrm{v} / \mathrm{v})$ hydrogen in the gas mixture.

In the present work, the endogenous factor $\mathrm{F}_{420}$ was used as an intrinsic $\mathrm{pH}$ indicator. It fulfils most of the requirements cited above for a cytoplasmic $\mathrm{pH}$ indicator.

\section{METHODS}

All chemicals used were of highest analytical grade and were obtained from Fluka, Sigma or Merck. Gases were obtained from Carbagas.

Organism, growth medium and growth conditions. $M$. thermoautotrophicum strain Hveragerdi (DSM 3590) was isolated earlier in our laboratory (Butsch \& Bachofen, 1984). Stock cultures were kept at $-80^{\circ} \mathrm{C}$. The medium was based on that of Schönheit et al. (1979), as modified by Butsch \& Bachofen (1984), and contained the following: $\mathrm{NH}_{4} \mathrm{Cl}$ (40 mM), $\mathrm{MgCl}_{2} \cdot 6 \mathrm{H}_{2} \mathrm{O}(1.5 \mathrm{mM})$, nitrilotriacetate $(0.15 \mathrm{mM})$, $\mathrm{NaCl}(10 \mathrm{mM}), \mathrm{KH}_{2} \mathrm{PO}_{4}(10 \mathrm{mM}), \mathrm{CoCl}_{2} \cdot 6 \mathrm{H}_{2} \mathrm{O}(1 \mu \mathrm{M})$, $\mathrm{Na}_{2} \mathrm{MoO}_{4} \cdot 2 \mathrm{H}_{2} \mathrm{O}(1 \mu \mathrm{M}), \mathrm{NiCl}_{2} \cdot 6 \mathrm{H}_{2} \mathrm{O}(1 \mu \mathrm{M})$ and $\mathrm{FeCl}_{2} \cdot 4 \mathrm{H}_{2} \mathrm{O}$ $(25 \mu \mathrm{M})$. Cells were grown in chemostat mode in a 21 bioreactor equipped with controls for temperature, $\mathrm{pH}$ and redox potential, as described by Jud et al. (1997). The temperature was held at $58^{\circ} \mathrm{C}$ and the $\mathrm{pH}$ at 6.9 . The culture was supplied with $\mathrm{Na}_{2} \mathrm{~S}(310 \mathrm{mM})$ at intervals, producing a final concentration of $0.5 \mathrm{mM}$ sulfide in the reactor. The gas supplied was $\mathrm{H}_{2} / \mathrm{CO}_{2}, 80 \%: 20 \%(\mathrm{v} / \mathrm{v})$; the rate was controlled electronically and kept at $220 \mathrm{ml} \mathrm{min}{ }^{-1}$ (equal to $0 \cdot 12$ vol. per vol. per min). Traces of oxygen were removed by a BASF catalyst, R0-20, sealed in an iron tube in the gas supply line. The sterile media were kept under nitrogen.

Spectroscopic investigations. The absorption spectra of solutions were obtained with a Uvicon 810 spectrophotometer. Optical measurements of cell suspensions were obtained with an Aminco DW-2 dual-wavelength spectrophotometer using either specially made anaerobic cuvettes with rubber septa or a $30 \mathrm{ml}$ minibioreactor built in our workshop and coupled to the DW-2 optics by light pipes. The spectrophotometer was connected to a computer with an ADALAB A/D converter (Interactive Microware).
Gas analysis. Hydrogen, methane, oxygen, carbon monoxide and carbon dioxide were quantified by gas chromatography [using a Shimadzu GC-R1A with integrator RPR-G1 and a CSS column Carbosieve S 120/140 (Supelco)] with a TCD detector. The gas was supplied reproducibly to the cuvettes and the minibioreactor through a stainless steel needle as pulses of $10 \mathrm{~s}$ at a flow rate of $240 \mathrm{ml} \mathrm{min}^{-1}$ by a computercontrolled valve.

Cell preparations. Cells were harvested by centrifugation $\left(15 \mathrm{~min}\right.$ at $\left.1800 \mathrm{~g}, 4^{\circ} \mathrm{C}\right)$ and washed twice with growth medium. All steps were performed under anoxic conditions using bottles flushed nine times with nitrogen (cycling between 0.5 and 2 bar). For the experiments, the cell concentration, measured as $\mathrm{OD}_{660}$, was set between 1.5 and 2, which is equivalent to $0 \cdot 8-1 \cdot 1 \mathrm{~g}$ cells (dry weight) $\mathrm{l}^{-1}$. The suspension was transferred either into an anaerobic cuvette equipped with a valve for gas pulses or into the minibioreactor in an anaerobic box (Forma Scientific 1024). To ensure the complete absence of oxygen, all glassware was kept in the anaerobic box for $24 \mathrm{~h}$ prior to the experiments. All manipulations were done under strictly anaerobic conditions, in closed vessels under purified nitrogen or in the anaerobic glove box. If these precautions for anoxic conditions were observed, the cells could be used reproducibly in experiments over a period of at least $4 \mathrm{~h}$.

Measurement of the $\mathrm{pH}_{\mathrm{in}}$. The cuvette or the minibioreactor was stirred and kept at constant temperature under strictly anaerobic conditions during the measurements. The Aminco DW-2 spectrophotometer was used in the dual-wavelength mode, which allows the quantification of small absorption changes in the presence of a large optical background signal (cell scatter). The determination of the relevant wavelengths and the calibration of the intracellular $\mathrm{pH}\left(\mathrm{pH}_{\mathrm{in}}\right)$ are described in Results.

Isolation of $\mathbf{F}_{420} \cdot \mathrm{F}_{420}$ was isolated, according to Cheeseman et al. (1972) and Schönheit et al. (1981), by extracting the compound using $50 \%(\mathrm{v} / \mathrm{v})$ acetone followed by chromatography twice on QAE-Sephadex A-25.

Other determinations. The minibioreactor was equipped with electrodes for the continuous measurement of $\mathrm{pH}$, redox potential and $\mathrm{Na}^{+}$ions (Ingold). The $\mathrm{OD}_{600}$ of the cell suspension was calibrated by using dry-weight determination.

\section{RESULTS AND DISCUSSION}

Previous experiments using CF demonstrated a hydrogen-induced change in absorption which was interpreted as a rise in intracellular $\mathrm{pH}$ (Bachofen \& Butsch, 1986). However, the spectrum of CF overlaps with that of the intrinsic electron carrier, $\mathrm{F}_{420}$, and no useful calibration was obtained with CF. Similarly, carboxynaphthofluorescein could not be used satisfactorily as an indicator for the intracellular $\mathrm{pH}$, although it has an absorption maximum shifted $100 \mathrm{~nm}$ to longer wavelengths. Factor $\mathrm{F}_{420}$ has a defined absorption spectrum (Fig. 1) that changes upon reduction and also shows a typical fluorescence. This allows methanogens to be easily distinguished from other bacteria in environmental samples (Cheeseman et al., 1972). Furthermore, the signal has been found to be proportional to the biomass (Reuter et al., 1986). As the absorption spectrum of $\mathrm{F}_{420}$ is also dependent on $\mathrm{pH}$ (Cheeseman et 


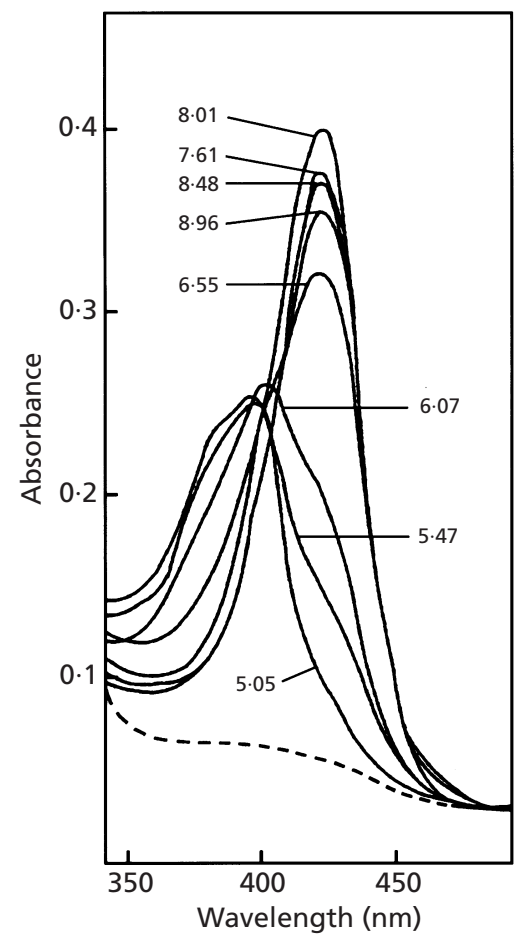

Fig. 1. $\mathrm{pH}$ dependence of the absorption spectrum of isolated oxidized $\mathrm{F}_{420}$. Gas phase, $\mathrm{N}_{2} ; \mathrm{F}_{420}, 10 \mu \mathrm{g} \mathrm{ml}^{-1}$. Buffer used: $\mathrm{pH}$ 8-9, $50 \mathrm{mM}$ Tris/HCl; below $\mathrm{pH} 8,20 \mathrm{mM} \mathrm{KH_{2 }} \mathrm{PO}_{4}$. Dashed line: $F_{420}$ reduced with dithionite.

al., 1972; Eirich et al., 1978), it can serve as a $\mathrm{pH}$ indicator to measure changes in the $\mathrm{pH}$ in the cytoplasm.

Fig. 1 shows absorption spectra in the visible range for the oxidized form of $\mathrm{F}_{420}$ at different $\mathrm{pH}$ values. To prevent irreversible degradation, the spectra of oxidized $\mathrm{F}_{420}$ were taken under nitrogen in the absence of an electron donor. A quasi-isosbestic point is obvious at $400 \mathrm{~nm}$ and maximum absorption changes are observed at $420 \mathrm{~nm}$. As the spectrum of $\mathrm{F}_{420}$ is also dependent on its redox state, the absorption at the isosbestic point at $400 \mathrm{~nm}$ is a measure of the redox state independent of the $\mathrm{pH}$. Full reduction of isolated $\mathrm{F}_{420}$ by dithionite causes the absorption peak to disappear. The change in absorption at $420 \mathrm{~nm}$ relative to that at $400 \mathrm{~nm}$ correlates well with the $\mathrm{pH}$ of the solution. Thus the absorption at $400 \mathrm{~nm}$ relative to the value of the fully oxidized state is indicative of the reduction state of $\mathrm{F}_{420}$. To compensate for variations in $\mathrm{F}_{420}$ concentrations in different preparations, both wavelengths, 400 and $420 \mathrm{~nm}$, are related to the absorption at $450 \mathrm{~nm}$ as the reference wavelength [ratio $\left.\left(A_{420}-A_{450}\right) /\left(A_{400}-A_{450}\right)\right]$. For isolated $\mathrm{F}_{420}$, the calibration curve is linear between $\mathrm{pH} 5.8$ and $\mathrm{pH} 7 \cdot 5$. Using the same wavelengths, a calibration curve was obtained for whole cells of $M$. thermoautotrophicum. Schönheit \& Beimborn (1985) and Bachofen \& Butsch (1986) demonstrated that no measurable proton potential is present under deenergized conditions in the absence of an electron donor,

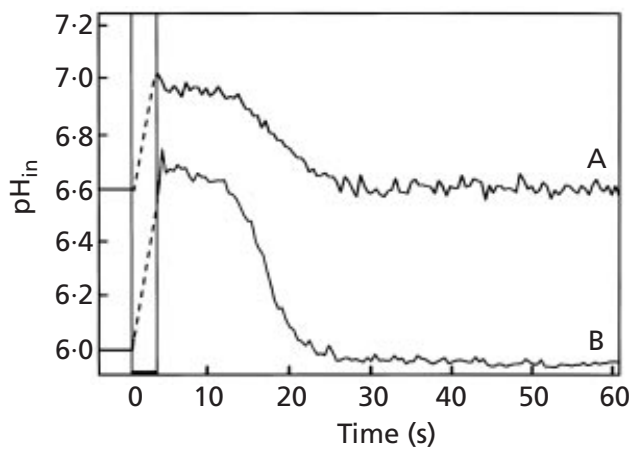

Fig. 2. Time course of the $\mathrm{pH}_{\mathrm{in}}$ after a $10 \mathrm{~s} \mathrm{H}_{2} / \mathrm{CO}_{2}(80: 20)$ pulse (black bar) at different medium pH values: $\mathrm{A}, \mathrm{pH} \mathrm{6.6;} \mathrm{B,} \mathrm{6.0.} \mathrm{Gas}$ flow rate during pulse, $240 \mathrm{ml} \mathrm{min}^{-1} ; T, 42^{\circ} \mathrm{C}$; mean of five experiments.

and that the $\mathrm{pH}_{\mathrm{in}}$ is then in equilibrium with, and thus equal to, the external $\mathrm{pH}\left(\mathrm{pH}_{\text {out }}\right)$. Measurements were taken with cell suspensions equilibrated under nitrogen at medium $\mathrm{pH}\left(\mathrm{pH}_{\text {out }}\right)$ values between $5 \cdot 8$ and $7 \cdot 2$. This ratio method makes the $\mathrm{pH}$ determinations independent of the intracellular concentration of the marker, $\mathrm{F}_{420}$, and compensates for parallel absorption changes of unknown compounds or variable scattering effects of cell suspensions (Kotyk \& Slavik, 1989).

The experiment presented in Fig. 2 is an example showing the kinetics of the changes in $\mathrm{pH}_{\text {in }}$ as calculated from the calibration curve. The rapid alkalinization of the cytoplasm upon the substrate pulse cannot be visualized because bubbles produced during gas injection make optical measurements impossible. Under defined conditions, the duration of the alkalinization until the $\mathrm{pH}_{\text {in }}$ returned to the initial $\mathrm{pH}$ of the medium was highly reproducible within the same cell preparation but it could vary between cell batches. The redox potential in the medium did not change after a hydrogen pulse (not shown). The size of the $\mathrm{pH}$ increase in the cytoplasm was dependent on the $\mathrm{pH}_{\text {out }}$ : it is larger at acid values of the medium $\mathrm{pH}$ and becomes smaller towards neutrality. Around neutrality, Schönheit \& Beimborn (1985) found, using M. thermoautotrophicum, that they could not measure a $\Delta \mathrm{pH}$ under metabolically active conditions; in a more acidic environment ( $\mathrm{pH}$ 5), however, the cytoplasm was found to be more alkaline, resulting in a $\mathrm{pH}$ gradient of $1-1 \cdot 3$ $\mathrm{pH}$ units under energized conditions. This is in close agreement with our observations. In contrast, the $\Delta \mathrm{pH}$ reported by Dybas \& Konisky (1992) for Methanococcus voltae under growing conditions was only a few millivolts.

The duration of the signal change upon hydrogen addition characterizes the length of time for which the cells stay in an energized state, conditions when a $\mathrm{pH}$ gradient and a membrane potential are present across the membrane. This is governed by the amount of $\mathrm{H}_{2}$ taken up by the cells, the concentration of $\mathrm{H}_{2}$ reached in 


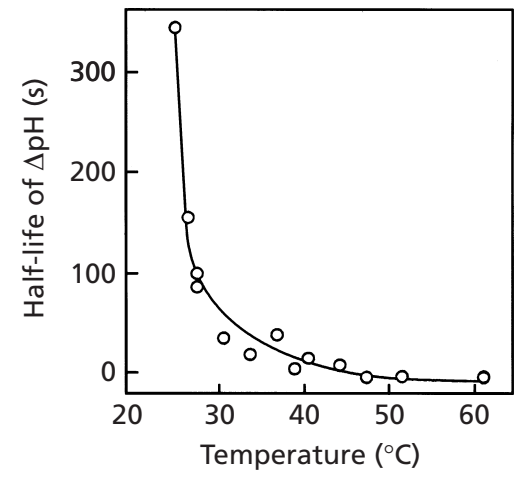

Fig. 3. Dependence on temperature of the half-life of the $\Delta \mathrm{pH}$ after a $10 \mathrm{~s} \mathrm{H}_{2} / \mathrm{CO}_{2}(80: 20)$ pulse. Gas flow rate during pulse,

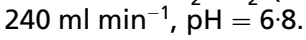

the medium after flushing, and (mainly) by the speed at which the electrons are used up in cellular metabolism. The length of the signal is determined from the time immediately after hydrogen injection (pulses of $\mathrm{H}_{2}$ / $\mathrm{CO}_{2}, 80: 20,10 \mathrm{~s}$ duration) to the time at which $50 \%$ decay is reached; it was strongly dependent on environmental factors such as temperature (Fig. 3). The decay of the hydrogen-induced proton gradient is rapid between $45^{\circ} \mathrm{C}$ and the growth temperature of $58^{\circ} \mathrm{C}$, but slows down rapidly at lower temperatures - a temperature-dependence similar to that of the growth rate of the organism.

Control experiments with a nitrogen $/ \mathrm{CO}_{2}$ mixture $(80: 20)$ and with inactivated denatured cells (stirred for $48 \mathrm{~h}$ under air, conditions in which $\mathrm{F}_{420}$ is rapidly inactivated and converted to factor $_{390}$ (Hausinger et al., 1985; Schönheit et al., 1981) prove that the hydrogeninduced $\mathrm{pH}$ changes are driven by the bacterial metabolism.

It has been suggested that $\mathrm{F}_{420}$ is not homogeneously distributed within the cell but is, rather (for functional reasons) concentrated near the membrane at the site of the hydrogenase (Muth, 1988). Thus, an averaging method such as the distribution of weak acids and bases (Schönheit \& Beimborn, 1985) or measurement with homogeneously distributed indicator dyes may not give the same values as a more localized $\mathrm{pH}$ indicator (Kotyk \& Slavik, 1989). The $\mathrm{pH}_{\mathrm{in}}$ measured by $\mathrm{F}_{420}$ probably does not indicate the mean $\mathrm{pH}$ within the cell but, rather, represents the $\mathrm{pH}$ found close to the membrane. This would support the suggestion that the pumped protons are held along the membrane by anionic lipids and are not in equilibrium with the cytoplasm (Haines, 1983).

The concentration of $\mathrm{Na}^{+}$ions in the medium, important for the formation of the $\Delta \Psi$ in methanogens, was measured simultaneously. It increases when hydrogen is supplied, and the return to the original value is delayed relative to the decay of the $\Delta \mathrm{pH}$. The decay clearly

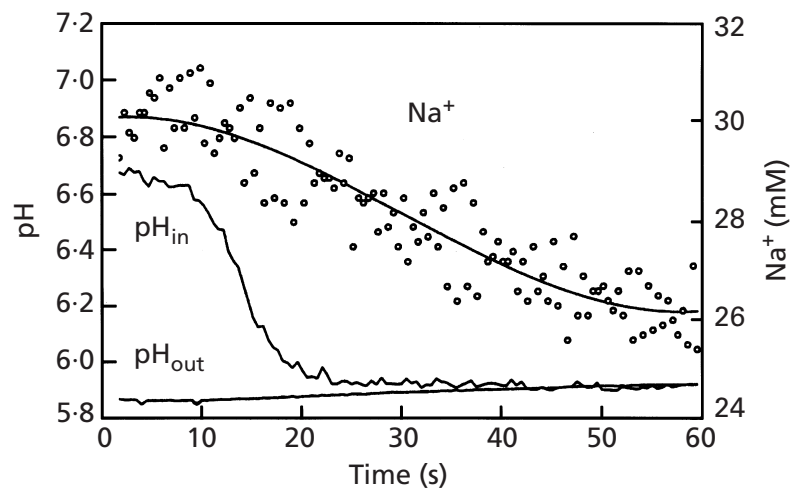

Fig. 4. Time course of intracellular and medium $\mathrm{pH}$, and extracellular $\mathrm{Na}^{+}$concentration after a $10 \mathrm{~s} \mathrm{H}_{2} / \mathrm{CO}_{2} \quad(80: 20)$ pulse. Gas flow rate during pulse, $240 \mathrm{ml} \mathrm{min}-1 ; T, 42^{\circ} \mathrm{C}$; mean of five experiments.

accelerates after the $\Delta \mathrm{pH}$ has dropped to below approximately $50 \%$ of the original size (Fig. 4). At the cell concentration chosen for the experiments, the ratio between the volume of medium and the volume of cells has been estimated to be approximately 600 . Thus, an $\mathrm{Na}^{+}$increase of a few millimoles per litre in the medium upon an $\mathrm{H}_{2}$ pulse would represent a drastic decrease in the ion concentration in the cell. Although most of the $\mathrm{Na}^{+}$ions may have been bound to cell components, it indicates the formation of a noticeable membrane potential. Indeed, it has been suggested that $\mathrm{Na}^{+}$and $\mathrm{K}^{+}$ ions are strongly complexed with specific lipids of the cell membrane (Kramer et al., 1988). The $\mathrm{Na}^{+}$efflux is probably the result of a directly coupled $\mathrm{Na}^{+}$pump, whereas the $\mathrm{Na}^{+} / \mathrm{H}^{+}$antiporter driven by $\mathrm{H}^{+}$extrusion during methanogenesis acts as a mechanism for regulating the $\mathrm{pH}_{\text {in }}$ (Deppenmeier et al., 1996; Schäfer et al., 1999). Because of the presence of $\mathrm{CO}_{2}$ in the gas pulse, the $\mathrm{pH}$ of the medium drops slightly and returns slowly (within 30-40 s) to the original value before the pulse (Fig. 4).

Inhibitors of methanogenesis, such as the uncoupler tetrachlorosalicylanilide (TCS), the $\mathrm{Na}^{+}$ionophore monensin, the inhibitor of the sodium-proton antiporter amiloride (for a review, see Kleyman \& Cragoe, 1988), and the analogue of Coenzyme $\mathrm{M}$ and inhibitor of the methylreductase, bromoethanesulfonic acid (BESA), were tested for effects on the hydrogen-induced $\mathrm{pH}_{\text {in }}$ changes. With TCS at $10 \mu \mathrm{M}$, the formation of a $\Delta \mathrm{pH}$ was completely abolished, which is typical of an uncoupling action. The other reagents altered the reaction kinetics less drastically (Table 1 ). Monensin at $10 \mu \mathrm{M}$ reduced the initial $\Delta \mathrm{pH}$ upon the $\mathrm{H}_{2}$ pulse and slowed down the signal recovery after the pulse. BESA showed no effects on the size of the $\Delta \mathrm{pH}$ up to $50 \mathrm{mM}$, but, again, the decay time also had increased. Amiloride at $10 \mu \mathrm{M}$ had some effect on the initial size of the $\Delta \mathrm{pH}$ and also retarded the decay kinetics. A prolonged signal duration is indicative of a longer lifetime of the $\mathrm{pH}$ 
Table 1. Effect of inhibitors on the size and the decay time of the $\Delta \mathrm{pH}$ after a $10 \mathrm{~s} \mathrm{H}_{2} / \mathrm{CO}_{2}(80: 20, \mathrm{v} / \mathrm{v})$ pulse

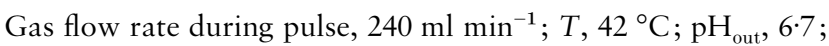
mean of 4-10 experiments).

\begin{tabular}{|lcc|}
\hline Inhibitor & $\Delta \mathbf{H}$ & $\begin{array}{c}\text { Decay time } \\
(\mathbf{s})^{*}\end{array}$ \\
\hline None (control) & $0 \cdot 26$ & 40 \\
Amiloride $(10 \mu \mathrm{M})$ & $0 \cdot 18$ & 130 \\
Monensin $(10 \mu \mathrm{M})$ & $0 \cdot 10$ & 180 \\
Tetrachlorosalicylanilide $(10 \mu \mathrm{M})$ & $0 \cdot 00$ & - \\
Bromoethanesulfonic acid $(50 \mathrm{mM})$ & $0 \cdot 27$ & 100 \\
\hline
\end{tabular}

* Time taken for the signal to decay to $50 \%$ of the original value.

gradient. In the presence of amiloride, the $\mathrm{Na}^{+} / \mathrm{H}^{+}$ antiporter, and thus the conversion of a $\Delta \mathrm{pH}$ into a $\Delta \mathrm{Na}^{+}$, is blocked. Similar effects of amiloride were noted by Müller et al. (1987) for Methanosarcina barkeri. Monensin abolishes part of the $\Delta \mathrm{pH}$, probably as a consequence of the higher $\mathrm{Na}^{+}$permeability.

\section{Conclusions}

Following absorption changes of the endogenous marker $\mathrm{F}_{420}$ at three wavelengths allows the determination of $\mathrm{pH}$ changes in the cytoplasm of whole cells of methanogenic bacteria. The $\Delta \mathrm{pH}$ is dependent on the external $\mathrm{pH}$; its decay is determined by the metabolism and affected by external factors. Furthermore, it is influenced by inhibitors of proton and sodium transport.

\section{ACKNOWLEDGEMENTS}

We thank the Swiss National Science Foundation for generous support (grant no. 32-27583.89), the unknown reviewers for their work in improving the manuscript, and D. Bollier for the construction of the minibiofermenter.

\section{REFERENCES}

Aono, R., Ito, M. \& Horikoshi, K. (1997). Measurement of cytoplasmic $\mathrm{pH}$ of the alkaliphile Bacillus lentus C-125 with a fluorescent $\mathrm{pH}$ probe. Microbiology 143, 2531-2536.

Bachofen, R. \& Butsch, B. (1986). Measurement of $\Delta \mathrm{pH}$ and electron transport activities in Methanobacterium thermoautotrophicum. Syst Appl Microbiol 7, 349-353.

Breeuwer, P., Drocourt, J. L., Rombouts, F. M. \& Abee, T. (1996). A novel method for continuous determination of the intracellular $\mathrm{pH}$ in bacteria with the internally conjugated fluorescent probe 5 (and 6-)-carboxyfluorescein succimidyl ester. Appl Environ Microbiol 62, 178-183.

Butsch, B. \& Bachofen, R. (1984). The membrane potential in whole cells of Methanobacterium thermoautotrophicum. Arch Microbiol 138, 293-298.

Cheeseman, P., Toms-Wood, A. \& Wolfe, R. S. (1972). Isolation and properties of a fluorescent compound, factor ${ }_{420}$, from Methanobacterium strain M.o.H. J Bacteriol 112, 527-531.
Deppenmeier, U., Müller, V. \& Gottschalk, G. (1996). Pathways of energy conservation in methanogenic archaea. Arch Microbiol $165,149-163$.

Dybas, M. \& Konisky, J. (1992). Energy transduction in the methanogen Methanococcus voltae is based on a sodium current. J Bacteriol 174, 5575-5583.

Eirich, L. D., Vogels, G. D. \& Wolfe, R. S. (1978). Proposed structure for Coenzyme $\mathrm{F}_{420}$ from Methanobacterium. Biochemistry 17, 4583-4593.

Haines, T. H. (1983). Anionic lipid headgroups as a protonconducting pathway along the surface of membranes: a hypothesis. Proc Natl Acad Sci US A 80, 160-164.

Hausinger, R. P., Orme-Johnson, W. H. \& Walsh, C. (1985). Factor 390 chromophores: phosphodiester between AMP or GMP and methanogen factor ${ }_{420}$. Biochemistry 24, 1629-1633.

Jud, G., Schneider, K. \& Bachofen, R. (1997). The role of hydrogen mass transfer for the growth kinetics of Methanobacterium thermoautotrophicum in batch and chemostat cultures. I Ind Microbiol Biotechnol 19, 246-251.

Kleyman, T. R. \& Cragoe, E. J. (1988). Amiloride and its analogs as tools in the study of ion transport. J Membr Biol 105, 1-21.

Kotyk, A. \& Slavik, J. (1989). Intracellular $p H$ and Its Measurement. Boca Raton, FL: CRC Press.

Kramer, J. K. G., Sauer, F. D. \& Bundle, D. R. (1988). The presence of tightly bound $\mathrm{Na}^{+}$or $\mathrm{K}^{+}$in glycolipids of Methanobacterium thermoautotrophicum. Biochim Biophys Acta 961, 285-292.

Müller, V., Blaut, M. \& Gottschalk, G. (1987). Generation of a transmembrane gradient of $\mathrm{Na}^{+}$in Methanosarcina barkeri. Eur J Biochem 162, 461-466.

Muth, E. (1988). Localization of the $\mathrm{F}_{420}$-reducing hydrogenase in Methanococcus voltae cells by immuno-gold technique. Arch Microbiol 150, 205-207.

Padan, E., Zilberstein, D. \& Schuldiner, S. (1981). $\mathrm{pH}$ homeostasis in bacteria. Biochim Biophys Acta 650, 151-166.

Reuter, B. W., Egeler, T., Schneckenburger, H. \& Schoberth, S. M. (1986). In vivo measurement of $\mathrm{F}_{420}$ fluorescence in cultures of Methanobacterium thermoautotrophicum. J Biotechnol 4, 325-332.

Schäfer, G., Engelhard, M. \& Müller, V. (1999). Bioenergetics of the Archaea. Microbiol Mol Biol Revs 63, 570-620.

Schönheit, P. \& Beimborn, D. B. (1985). ATP synthesis in Methanobacterium thermoautotrophicum coupled to $\mathrm{CH}_{4}$ formation from $\mathrm{H}_{2}$ and $\mathrm{CO}_{2}$ in the apparent absence of an electrochemical proton gradient across the cytoplasmic membrane. Eur J Biochem 148, 545-550.

Schönheit, P., Moll, J. \& Thauer, R. K. (1979). Nickel, cobalt, and molybdenum requirement for growth of Methanobacterium thermoautotrophicum. Arch Microbiol 123, 105-107.

Schönheit, P., Keweloh, H. \& Thauer, R. K. (1981). Factor $F_{420}$ degradation in Methanobacterium thermoautotrophicum during exposure to oxygen. FEMS Microbiol Lett 12, 347-349.

Siegumfeldt, H., Rechinger, K. B. \& Jakobsen, M. (1999). Use of fluorescence ratio imaging for intracellular $\mathrm{pH}$ determination of individual bacterial cells in mixed cultures. Microbiology 145, 1703-1709.

Thomas, J. A., Buchsbaum, R. N., Zimniak, A. \& Racker, E. (1979). Intracellular $\mathrm{pH}$ measurements in Ehrlich ascites tumour cells utilizing spectroscopic probes generated in situ. Biochemistry 18, 2210-2218.

Thomas, J. A., Kolbeck, P. C. \& Langworthy, T. A. (1982). Spectrophotometric determination of cytoplasmic and mitochondrial $\mathrm{pH}$ 
transitions using trapped $\mathrm{pH}$ indicators. In Intracellular $\mathrm{pH}$, Its Measurement, Regulation, and Utilization in Cellular Function, pp. 105-123. Edited by R. Nuccitelli \& D. Deamer. New York: A. R. Liss.

Yassine, M., Salmon, J. M., Vigo, J. \& Viallet, P. (1997). C-SNARF1 as a $\mathrm{pH}_{\mathrm{i}}$ fluoroprobe: discrepancies between conventional and intracellular data do not result from protein interactions. $J$ Photochem Photobiol B 37, 18-25.

Received 22 May 2000; revised 30 August 2000; accepted 12 September 2000. 